\title{
PUBLIC PRIVATE PARTNERSHIP AS A DETERMINANT FACTORS OF AFFORDABLE HOUSING IN ABUJA NIGERIA.
}

\author{
Yahaya Ahmed $^{12^{*}}$, Ibrahim Atan Bin Sipan ${ }^{1}$ \\ ${ }^{1}$ Department of Property Management, Faculty of Built Environment \& Surveying, \\ University Technology Malaysia, 81310 Skudai, Johor, Malaysia, \\ yahmednas1@gmail.com, ibrahimsipan@utm.my \\ ${ }^{2}$ Department of Estate Management \& Valuation, Federal Polytechnic, P.M.B. 001, Nasarawa, Nasarawa State, Nigeria.
}

KEYWORD: Public Private Partnership Affordable Housing

\begin{abstract}
:
The implementation of Public-Private Partnership (PPP) in housing provision in Nigeria meant to increase urban housing provision and address housing affordability and accessibility problems. Consequently, the study aims to identify the critical success factors of Public-private partnerships for affordable housing provision in Nigeria. However, the data were obtained using interviews with PPP experts to build the questionnaire for affordable housing in Nigeria. Overall, 254 responses were obtained and analysed using smart PLS to identify PPP success factors for affordable housing in Abuja. The result shows that good governance, availability of financial markets, Sound economic policies, consistency monetary, a commitment of public and private sectors are the key parameters of PPP for affordable housing in Nigeria. Therefore, the main contributions of the article indicate that strong government intervention, dependent of foreign building materials, easier access to mortgage institutions, and provision of land at no cost are the challenges to address in order to succeed in providing affordable housing in Nigeria. It is therefore recommended that a good design a framework should put in place in order to achieve the desired aim of providing affordable housing in Nigeria.
\end{abstract}

\section{INTRODUCTION}

It is anticipated that by the year 2030, three billion people or approximately $40 \%$ of the world's population will face the challenges of adequate and affordable housing (UN-Habitat, 2006). The provision of housing is limited by the weak governance system and deficiency of people resources, and by the regulation and institutions which are lacking in capacity, poorly informed or obsolete (UN-Habitat, 2015). The housing crisis scale facing Nigeria has never been before. Every year, Nigeria constructs about 600,000 fewer homes than is needed, adding to the current 23 million deficit that has grown for decades. This deficit has accrued since the years of a supply shortage. To improve the delivery of affordable housing in Nigeria, this study suggests that the use of public-private partnerships (PPPs) as a tool, if used effectively, can increase private sector investment and fuel development initiatives. The key motivation is the opportunity for the government to bind cash to get new private financing sources to meet the cost of adequate housing provision (Babatunde et al., 2012).

However, an increase in affordable housing is recognized by the international community as one of the significant challenges of the development of the twenty-first century (Kissick et al., 2006; Walley, 2010). From the cumulative dwellers in developing countries to low-income households inexpensive global capital cities in developed countries, hundreds of millions of people are struggling to find decent housing that they can afford without severe financial pressures that have social and economic consequences (Woetzel et al., 2014). Globally, about 1.6 billion people live in weak housing, and 100 million have no homes (Kothari, 2005). Every week more than one million people are born or moved to cities in low-income countries, given the need for new and better housing (Kissick et al., 2006). The estimated total new housing requirements in Africa have been set at around 4 million units a year with more than 60 per cent of the demand needed to accommodate urban residents and this may increase to 5 million a year (Walley, 2010). This translates to nearly 14,000 homes daily to accommodate the expected population growth of the city.

Therefore, the lack of affordable housing has been recognized internationally as a deep and widespread problem, the strategy to address this problem seems to be not examined thoroughly (UNHabitat, 2005). Some policies, institutions, and regulations set by the Nigerian government since independence in 1960 have been barred by frequent government changes and this tends to disrupt the policies and programs before they have the opportunity to hold (FinMarkTrust, 2010). Although these initiatives may have an impact, they are not yet enough or effective enough to deliver housing to all Nigerians. Affordable housing financing is essential if the world is to maintain environmental sustainability, economic prosperity, cultural diversity and social equity (UN-Habitat, 2005).

Consequently, the policy debate over housing is still dominated by how the state can support the low-income housing market (Sa-Aadu, 1984). The multiplex nature of the term of affordable housing is throwback by the fact that ability is both a role of housing demand and supply factor (Bieri, 2012). Side-by-side programs usually block the private housing market while side-by-side programs rely on market discipline to promote affordable housing goals for those in need. Nigerian government is involved in a side-by-side approach (such as a Loan Refinancing a Company and the Federal Mortgage Bank) for couple of years to promote home ownership without great success. However, the UN recommends that African countries be more responsible for housing provision in the private sector through PPP (Ibem and Aduwo, 2012). Miraftab (2004) finds that public-Private Partnerships (PPPs) are recognized as an alternative institutional arrangement and approach to public services in cities in developing countries. In the provision of housing, PPP is promoted on the assumption that it will increase the capability of the housing sector, and the expansion of housing capability and facilities (Shelter Afrique, 2008). 
Based on this proposal the Nigerian government in 2004 adopted the PPP in the proposal to increase housing supply in the cities of the country of Abuja and Lagos (Owei, 2007). The government believes that PPP will improve efficiency in public administration and delivery of services through the editing of private and professional sector funds (Lagos State Government, 2008).

\section{THE REVIEW OF PAST POLICIES AND PROGRAMMES}

A safe, secure, accessible, affordable and clean housing provision is a human right, as enshrined in the United Nations Habitat Agenda (1996). This universally accepted principle has been recognized by the successive Nigerian Government, as evidenced by the pockets of initiatives and irregular programs in massive housing development (NHP, 2012). Despite these facts that housing delivery remains a major challenge. A significant deficit in housing provision is due to the lack of National Housing Policy (2012) to meet the present economic challenges and trends and to guide development in this sector. Additionally, the lack of social housing system (Gemade, 2011) and reducing low-cost housing have put pressure on low-income and middle-income families and individuals, especially those who have difficulties in accessing housing in the private market.

The Nigerian National housing policy was first launched in 1991. The main objective of the National Housing Policy is to ensure that all Nigerians own or have access to eligible, safe and hygienic accommodation at reasonable prices by the year 2000. Twenty-six (26) the first National Housing Policy was launched, Nigeria had no clear National Land Policy, or the latest National Housing Policy. In Nigeria, studies have proven that the priorities of the policy of the former government suppliers are the lack of political, poor financing and lack of mortgage institutions, policy and institutional sustainability, political corruption, poor socioeconomic structures program politicization, (among others) has contributed greatly to failure (Awotona, 1990; Ndubueze, 2009; Aringo, 2008) Saka (1987) examined past policies and programs in Nigeria and noted that, although these policies have been well-planned, they have achieved little impact, as the programs originally planned to meet the needs of the lower-income group but were taken over by companies, income group. (Ogunshakin and Olayiwola, 1992) trace the root cause of the collapse of a major housing policy in Nigeria to a contradiction in the institutional mechanisms of decisionmaking and implementation processes, rather than the basic essence.

This propose that challenges in affordable housing relate to policy formulation, regulation and implementation and development and actual production of housing units and services. The main problem in past attempts at housing and urban development and in the building of a sustainable housing provision, and effective urban development and management in Nigeria is the absence of clear focus in pursuing the Ministry's mandate. Furthermore, stakeholder engagement and exceptions close to private sector investors in housing and service delivery rob the competition sector and the efficiency required for stability. The Government's inability is solely to finance the provision of housing and urban development resulting in huge vacancies and large requirements, which cannot be fulfilled in this sector.

The housing situation in Nigeria remains basically the same, one of the insufficiency and quantities. From the early year of 1999, housing developments were so abandon by successive governments, which was not regarded as a priority for many years and no budget allocation for housing for many years, 'no housing 'the situation is in Nigeria and about $60 \%$ of Nigerians are homeless. The federal government in 1999, start planning to for the new National Housing
Program where it will build twenty thousand $(20,000)$ houses across the Federation within four years at five thousand $(5,000)$ units each year as a demonstration of its commitment to eradicate housing problems among Nigerians. However, the programme was abandon because for some problems, poor infrastructure for housing delivery mechanisms and the reality that the Ministry of Public Works and Federal Housing proceed to be not equipped to handle the supply of housing to meet the needs of the State as it works for all practical purposes such as the Federal Ministry of Work Only (NHP, 2012).

\subsection{Overview of Affordable Housing in Nigeria}

Decent and affordable housing is an unmet need for millions of Nigerian households. Some studies show that there is only enough supply to meet the demand for affordable housing (Awotona, 1990, Ikejiofor, 1999; Salau, 1992; Ndubueze, Finmark Trust, 2010). According to the Center for Social Policy Studies, the lack of affordable housing can lead to high rent loads, unstable congestion and housing and unreliable housing for most Nigerian families (CCSP, 2011). Affordable housing is essential for the country and its people. The slamming community, the lost jobs, the weak economy, and the environment (Disabled, 2007). The need of affordable housing has become a profound and significant problem throughout Nigeria.

The government needs to provide decent housing with reasonable prices for a modest household income is embodied in the national housing policy (NHP, 2012). Many of these families have limited economic autonomy and cannot afford to buy their own home. The messenger for them appears to be the expansion of the residence where they now live and share with other family units, often close family relationships (UN-Habitat, 2011). Despite the increase in demand for affordable housing, such investments are not seen as commercial for housing developers, and limited investment by the non-government housing sector (Susilawati, 2009). However, private sector (formal and informal) contributions that provide more than 90 percent of the housing stocks in Nigeria hold firm to housing development (UN-Habitat, 2006, Ogbuozobe and Ogu, 2001). The main problem facing the private sector is the lack of finance to start a meaningful housing delivery service (Gbadeyan, 2011), barriers to land acquisition, high cost building materials, planning rules, and codes, housing infrastructure problems (World Bank, 1993). In addition, the lack of land supply, limited government subsidies and rising cost of housing do not offer incentives for investment in affordable housing either (Susilawati, 2009).

To significantly increase the national housing stock, the United Nations (2006) emphasizes that this sector needs to be mobilized, organized and motivated in line with the overall organizational structure of the housing delivery system (UN-Habitat, 2006). The current development trend in a country where private developers are involved in affordable commercial housing to some special people in the community, especially to make profits and not for the public (Adedeji and Olotuah, 2012). Since most developers operate on short-term loans that must be restored in a short period of time, the cost of these houses is very high and cannot be paid by middleincome earners who require them (Adedeji and Olotuah, 2012).

\subsection{PPP as Tool of Governance or Management}

The presence of public private partnership has been around for various years in domestic affairs of highly developed states (Börzel and Risse, 2002). The study of (Ameyaw and Chan, 2016; Börzel \& Risse, 2002; Teiseman and Klijn, 2002; Weihe, 2006; Khanom, 2010 ) consider public private partnerships as governance tools - as a significant solution to various governance issues (Reinicke and 
Deng, 2000). The study of Peter and Pierre (1998), postulate that there is a strong impression that the public sector has become isolated from and beyond touch with the whole community. While private sector companies, under severe pressure from market competition, have developed sophisticated resource management and allocation models, the public bureaucracy has long survived economic pressures. They are of the view that the public service has been slowly occurring; have widespread inefficiency; was satisfied with the economy; have an obsession with the proper process and do not care about the needs of the people (Peters and Pierre, 1998). In addition, the rationale and key catalyst for increased private sector participation in the provision of public services were provided by poor performance and mismanagement which characterized most public utilities and public operations (Shambaugh, 1999).

(Linder and Rosenau, 2000) defines the public private partnership from the perspective of public management as "the establishment of intergovernmental cooperation, profit-making firms, and non-profit private organizations to meet the basic functions". This arrangement tends to focus on aspects of relationship organization such as cooperation and cooperation (Khanom, 2010). The use of collaboration leads to the mix of the public sector and private sector resources. This arrangement allows mutual use of resources and the merging of public and private attributes in a way that may not be viable in conventional structural arrangements (Peter and Pierre, 1998) or allowing each party to use unusable sources it remains independent (Peters, 1998) . For example, the government may be able to avoid some procedural requirements that may restrict its operations, while the private sector may obtain government approval and funds for projects that may be difficult to obtain without such resources.

The key policy important for any government seeking PPP is the increased significance on enhancing the effectiveness and quality of public services and most significant driver for PPP development is the identification of the responsibilities that the private sector will play in achieving the objective of expanding the quantity and quality of public services. PPP offers opportunities for private sector efficiency and introducing appropriate risk sharing mechanisms between public and private sectors (EIB, 2004). This has motivate numerous governments, furthermore the Nigerian government, to safeguard a proper regulatory environment, and a legal framework, plan to support expand private sector participation in the delivery of public services.

So far, the introduction of PPP has been largely evaluated through a conceptual framework that highlight either the management, financial, administrative or technical measure of this reform strategy (Flinders, 2005). The fundemental difference between the functions of the public and private sectors is that the government responds to national interests and concerns, while private companies are driven by imperatives to maximize profits.

\subsection{Public-Private Partnership in Housing}

The public sector has worked hard to formulate, implement and finance effectively and efficient delivery of housing policies in Nigeria have many services to be provided to citizen but with limited resources. However, be aware of the fact that private homeowners and the rental housing sector have and will continues to be the main supplier of major housing in the country, the recent adoption of public-private partnership by the Nigerian Government is the reforming the housing sector in the new State Housing Policies 2006 (Aluko, 2009).

The history of housing delivery in Nigeria stated that the public sector has played a dominant role and since then the fact that the private sector is a major provider of housing in Nigeria even with the motive of financial gain, the government should act as "an actor's facilitators and facilitators to individual housing and cooperative businesses that are not acting as real estate executives (Aluko, 2009). It is at this point that Agbola (1998) recommends the integration of both private and public parties' resources as a functioning framework to promote private sector participation in housing delivery. In the same venous, Mabogunje (1993) also agrees that the problem or constraints are waging on the successful participation of the private sector in the delivery of housing should be addressed through public-private partnership if housing and urban development will be promoted in Africa. Capital for publicprivate partnership in the provision of housing on a large scale involves two major actors and other stakeholders used by the main actor. The main actor is the public sector (Government at any level) and the private sector (Property Development). The Company) while other stakeholders may be financial institutions, insurance companies, construction companies, building materials suppliers etc.

\subsection{Why Public private partnership will be an Effective Instrument for Affordable Housing}

The HM-Treasury Assessment of PPP has shown that PPP elements exist, offering benefits. These include project management skills, innovation and risk management, such as, ensuring that buildings are delivered to high quality, by time and budget and these assets are maintained to a high standard throughout their lifetime (Treasury HM, 2012). For the public sector working to improve affordable housing, partnerships with private sector organizations have the potential to increase the resources, finance and expertise available for the project and enable the project to reach a broader target group of households. While study on this subject is few, there are several reasons to agree that partnership offers a way forward in the provision and management of affordable housing (Moskalyk, 2008). Sharing may not necessarily be the preferred solution but a worthy consideration to help address the needs of affordable housing. As listed below is the reason for adopting PPP as a tools for project delivery.

- Efficiency Gain

- Sources of Financing

- Better on-time construction performance

- Earlier delivery

- Protection of the Public Interest

\section{METHODOLOGY}

This study uses sequential mixing methods, the purpose of the design of sequential design methods involves the first qualitative data collection procedures to explore phenomena which was explore through the expert opinion, and then collect quantitative data to clarify the existing relationships in qualitative data. This research has used the focus group interview with PPP experts and identifies applicable success factors for the delivery of Public Private Partnership for affordable housing provision in Nigeria as identified from literature. The professional background respondents to the group interviews have identified their understanding of the PPP project. Pioneer surveys were conducted to examine the effectiveness of research tools using Cronbach Alpha and KaiserMeyer-Olkin statistical methods. The instrument is found to be reliable and effective in preparing the questionnaire.

As described by Kumar (2005), the questionnaire project should be from a literature review and validated through focus group interviews and tested before being used for comprehensive data collection. The questionnaire was distributed to stakeholders involved in public and private developers who provide PPP in the 
study area. the total of 350 questionnaires were randomly assigned to FCT's target audience (stakeholders of public and private sector officials) to participate in PPP housing and real estate developers, which returned 254 questionnaires. The data from questionnaire survey were analyzed using PPSS software for factor analysis and smart PLS used to analyze data.

\section{RESULTS AND DISCUSSION}

a. Demographic of the respondent

\begin{tabular}{|c|c|c|}
\hline \multicolumn{2}{|r|}{ AgeGroup } & Types of PPP project Participated \\
\hline Over 41 years & $21.50 \%$ & Infrastructure $13.30 \%$ \\
\hline 25 to 40 years & $68 \%$ & Housing provision \\
\hline Less than 25 years & $=14.50 \%$ & None $-14.50 \%$ \\
\hline & $.00 \% 0.00 \% 0.00860 .00 \% 0.00 \%$ & $0.00 \% 0.00 \% 0.00 \% 0.00 \% 0.00 \%$ \\
\hline (a) & & (b) \\
\hline
\end{tabular}

Figure1 Age group and types of PPP project Participated

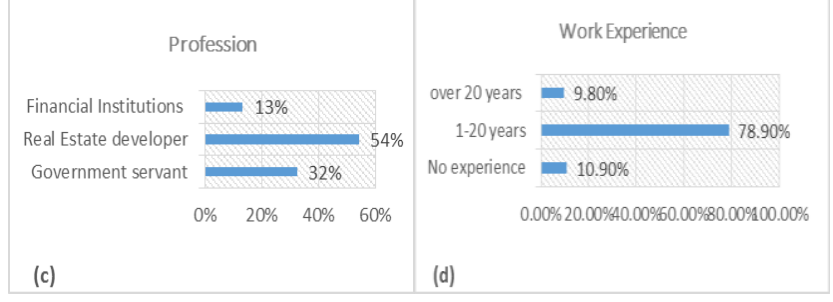

Figure 2 Profession and Work experience

Most of the respondents that participated in PPP project worked for a good number of years in the PPP project From Figure 1(a), it can be deduced that the respondents had the necessary experience to carry out this research survey because 78.9 per cent of the respondents had at least one to 20 years working experience, while over 20 years has 25.8 per cent and those without experience has only $10.9 \%$ in PPP project.

Figure 1(b) indicates the types of PPP project in Nigeria with those participated in PPP housing project has the highest of 72.3 per cent, while those that participated in infrastructural development has 13.3 percent, and those who work as PPP staff without participating in any project but has knowledge of PPP has 14.5 percent.

The role played by the different professional in PPP housing project in Nigerian is shown in Figure 2(a). Respondents from the financial institution has 13 percent, Real estate developers constitute the highest with 54 per cent, 32 per cent from the government servant. These shows that the respondents are from the real domain of research under investigation. This shows a reliable to the data used for this research.

Figure 2(b) shows the extent of familiarity on respondent for PPP housing project in Nigerian. The response prove that 78.9 per cent of the respondents were close associate with the PPP housing project, while those with over 20 years' experience has 9.8 per cent and those who work for PPP and have the knowledge without experience have 10.9 percent respectively. It is imperative to note that about 88.7 per cent of the respondents are either totally familiar, familiar, or moderately familiar with PPP housing project in Nigeria.

Figure 3. Shows that the experts have a $73.5 \%$ agreement on PPP CSF to provide affordable housing. This shows that according to expert opinion, thirty-nine CSFs are important. However, these 39 CSFs were used for pilot studies and to find out their reliability and effectiveness. After obtaining the reliability, validity, and sampling adequacy of the research tool, the study conducted a comprehensive questionnaire in subsequent chapters.

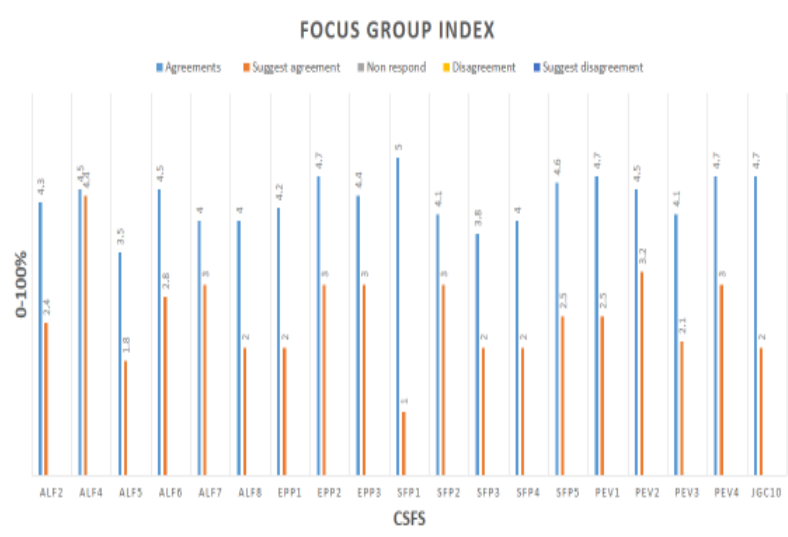

Figure 3. Focus Group Agreement Index

Figure 1.1 shows the critical success factors of public private partnership having a second order construct and Tables 1.1 and 1.2 showing the composite reliability, Convergent validity and discriminant validity respectively. the reflective measurement models for the adequate legal framework, effective procurement process, sound financial package, project economic viability, judicial government control, and strong private sector when analyzing composite reliability adequate legal framework had nine indicators, effective procurement process had three indicators, sound financial package also had five indicators, project economic viability has four indicators, judicial government control has thirteen indicators and strong private sector has five indicators.

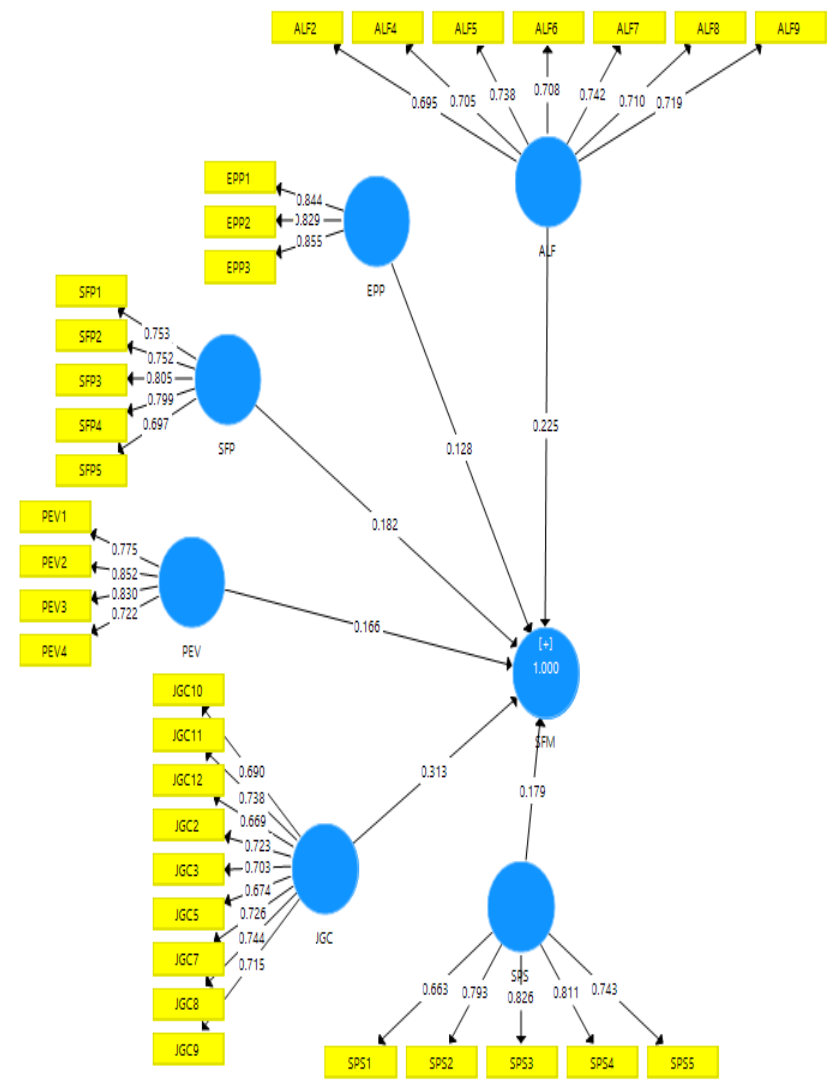

Figure 1.1 critical success factors structural model (SFM) 
Table 1.1 Composite Reliability and Convergent Validity of Public Private Partnership problems Model

\begin{tabular}{|c|c|c|c|c|c|c|}
\hline $\begin{array}{l}\text { 1st } \\
\text { order } \\
\text { Const } \\
\text { ruct }\end{array}$ & $\begin{array}{l}\text { 2nd order } \\
\text { Construct }\end{array}$ & Items & $\begin{array}{l}\text { Measure } \\
\text { ment } \\
\text { Model } \\
\text { Type }\end{array}$ & $\begin{array}{l}\text { Loadin } \\
\text { g }\end{array}$ & CR & AVE \\
\hline \multirow{6}{*}{ 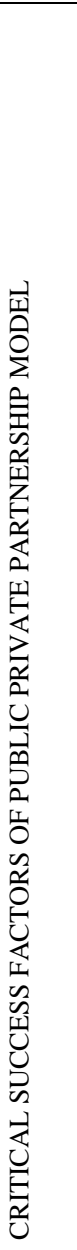 } & $\begin{array}{l}\text { Adequate } \\
\text { Legal } \\
\text { Framework }\end{array}$ & $\begin{array}{l}\text { ALF2 } \\
\text { ALF4 } \\
\text { ALF5 } \\
\text { ALF6 } \\
\text { ALF7 } \\
\text { ALF8 } \\
\text { ALF9 }\end{array}$ & Reflective & $\begin{array}{l}0.695 \\
0.705 \\
0.738 \\
0.708 \\
0.742 \\
0.710 \\
0.719\end{array}$ & 0.881 & 0.514 \\
\hline & $\begin{array}{l}\text { Effective } \\
\text { procuremen } \\
\text { t process }\end{array}$ & $\begin{array}{l}\text { EPP1 } \\
\text { EPP2 } \\
\text { EPP3 }\end{array}$ & Reflective & $\begin{array}{l}0.844 \\
0.829 \\
0.855\end{array}$ & 0.880 & 0.710 \\
\hline & $\begin{array}{l}\text { Sound } \\
\text { Financial } \\
\text { Package }\end{array}$ & $\begin{array}{l}\text { SFP1 } \\
\text { SFP2 } \\
\text { SFP3 } \\
\text { SFP4 } \\
\text { SFP5 }\end{array}$ & Reflective & $\begin{array}{l}0.753 \\
0.752 \\
0.805 \\
0.799 \\
0.697\end{array}$ & 0.901 & 0.581 \\
\hline & $\begin{array}{l}\text { Project } \\
\text { Economic } \\
\text { Viability }\end{array}$ & $\begin{array}{l}\text { PEV1 } \\
\text { PEV2 } \\
\text { PEV3 } \\
\text { PEV4 }\end{array}$ & Reflective & $\begin{array}{l}0.775 \\
0.852 \\
0.830 \\
0.722\end{array}$ & 0.874 & 0.634 \\
\hline & $\begin{array}{l}\text { Judicial } \\
\text { Governmen } \\
\text { t control }\end{array}$ & $\begin{array}{l}\text { JGC1 } \\
0 \\
\text { JGC1 } \\
1 \\
\text { JGC1 } \\
2 \\
\text { JGC2 } \\
\text { JGC3 } \\
\text { JGC5 } \\
\text { JGC7 } \\
\text { JGC8 } \\
\text { JGC9 }\end{array}$ & Reflective & $\begin{array}{l}0.690 \\
0.738 \\
0.660 \\
0.723 \\
0.703 \\
0.674 \\
0.726 \\
0.744 \\
0.715\end{array}$ & 0.874 & 0.573 \\
\hline & $\begin{array}{l}\text { Strong } \\
\text { Private } \\
\text { sector }\end{array}$ & $\begin{array}{l}\text { SPS1 } \\
\text { SPS2 } \\
\text { SPS3 } \\
\text { SPS4 } \\
\text { SPS5 }\end{array}$ & Reflective & $\begin{array}{l}0.663 \\
0.793 \\
0.826 \\
0.800 \\
0.743\end{array}$ & 0.878 & 0.592 \\
\hline
\end{tabular}

Table 1.2 Discriminant Validity

\begin{tabular}{|l|llllll|}
\hline & ALF & EPP_ & JGC & PEV & SFP & SPS \\
\hline ALF & & & & & & \\
EPP_ & 0.698 & & & & & \\
JGC & 0.715 & 0.773 & & & & \\
PEV & 0.758 & 0.845 & 0.889 & & & \\
SFP & 0.709 & 0.835 & 0.782 & 0.843 & & \\
SPS & 0.769 & 0.61 & 0.791 & 0.688 & 0.652 & \\
\hline
\end{tabular}

\subsection{Adequate Legal Framework (ALF) Construct}

Table 1.1 shows Adequate legal framework as one of the first construct which consist of the Commitment/responsibility of public/private sectors (ALF2) with loading point (0.695), Identification and understanding of client/owner requirement (ALF4) and a loading point of (0.705), Project Technical Feasibility (ALF5) also has a loading point of (0.738), Technology transfer (ALF6) with loading point (0.708), Available of competent personnel (ALF7) and a loading point of (0.742), Sound legal basis (ALF8) with a loading point of (0.710), and Robust and clear agreement (ALF9) also with a loading point of (0.719) respectively. Meanwhile, adequate legal framework has a composite reliability value of (0.881) and AVE of (0.514), this shows that adequate legal framework construct is very significant with a perfect model fit.
Adequate legal framework is to ensure the program stability and the recognition of beneficiaries as rights holders. Also the need to provide for strong legal frameworks that clearly lay out entitlements, rights and obligation, to ensure the safe, secure and peaceful planning (Jacobson and Choi, 2008).

However, these factors will help ensure the stability of the program and the beneficiaries' recognition as Nigerian rights holders, as some countries such as Malaysia, the United Kingdom and Australia have successfully improved affordable housing for all income groups.

\subsection{Effective procurement process (EPP) Construct}

Effective procurement process (EPP) as shown in Table 6.13 consist of Good governance (EPP1) with a loading point of (0.844), Competitive procurement process (EPP2) with a loading point of (829), Transparency procurement process (EPP3) has a loading point of (0.855). The composite reliability value of effective procurement process is $(0.881)$ and the AVE is (0.514) this shows a significant improvement in which all the EPP variables fall within acceptable value.

Effective procurement process (EPP) relates to how effective is the PPP procurement in terms transparency, competitiveness and principles of good governance. Other measures that determine the effectiveness of the procurement process are a well-organized and committed public agency, and trust and openness between partners (Chan et. At., 2005 \& Babatunde et al., 2012).

Therefore, the integrity of the partners involve and the transparent of the process are the key determinants of long-term success. There is need to be transparent, fair, trustworthy and confident in any successful collaborative project.

\subsection{Sound Financial Package (SFP) Construct}

Sound Financial Package (SFP) consist of five variable, Stable currencies of debts \& equity finance (SFP1) with loading point of (0.733), Repayment of the debt (SFP2) and a loading point of (0.752), Access to alternative fund (SFP3) has a loading point of (0.805), Financial capability (SFP4) with a loading point of (0.799), and Assessment of cost benefit (SFP5) with loading point of (0.697). However, the CR and AVE of Sound Financial Package (SFP) are (0.901) and (0.581) respectively. This indicate a significant fit model that will all variable fall within the accepted value. Sound financial package is a strategy in providing a sound financial system and also providing the most current and relevant financial planning in the development process (Jefferies (2002).

Therefore, the Nigerian government needs to support PPP through another financing means. By establishing more financial institutions, such as federal mortgage lenders, it is also necessary to reduce or control high interest rates. Providing subsidies will help reduce housing costs to low- and middle-income. By.

\subsection{Project Economic Viability (PEV) Construct}

Project Economic Viability (PEV) as shown in Table 6.15 consist of four variables, Available financial market (PEV1) with loading point of (0.755), Favourable investment environment (PEV2) with a loading point of (0.852), Stable macro-economic conditions (PEV3) also has loading point of (0.830), and Involvement of civil society (PEV4) and loading point of (0.722). Project Economic Viability (PEV) has a CR of (0.874) and AVE of (0.634) respectively. This indicate that PEV model is fit and significant with value within the acceptable point. 
Project economic viability, the project's economic viability is to assess whether the project is a good public investment decision based on economic viability analysis. This assessment may occur before consideration of a project as PPP as described in the PPP Project Identification. In other cases, it can be done as part of the PPP evaluation process. Project feasibility analysis and PPP economic viability analysis should be the same as other major public investment projects (Ismail, 2013).

\subsection{Judicial Government control (JGC) Construct}

As indicate in Table 6.16 Judicial Government control (JGC) Construct consist of six variables, such as; Action against errant developers (JGC10) has loading point of (0.690), Access to Land (JGC11) with loading point (0.738), Appropriate risk allocation (JGC12) with loading point of (0.660), Sound economic policy (JGC2) with loading point (0.723), Stable Political Environment (JGC3) with loading point (0.703), Strong political support (JGC5) has a loading point of (0.674), Share authority between the public \& private sector (JGC7) with loading point (0.726), Strong Government support (JGC8) also has a loading point of (0.744), and Consistent monitoring (JGC9) with a loading point (0.715). The Judicial Government control (JGC) Construct has a CR of (0.874) and AVE of (0.573). Therefore, Judicial Government control (JGC) model indicate a significant and accepted point. Judicious government control (JGC) involving government control exercises to ensure that all parties comply with established rules and regulations and discharge their responsibilities wisely. The variables under construction are based on the success factors identified from the literature studied (Chan et. al. 2005).

Therefore, continued improvement in the rule of law will help to build the investor confidence and promote the greater growth. Making sure that the government exercises some level of rights granted under the project agreement or specific rights granted by national laws, such as foreign exchange pledges, to ensure the company will not be appropriate without proper compensation, nor will it prevent the project company.

\subsection{Strong Private sector (SPS) Construct}

Strong Private sector (SPS) Construct has five variable as indicate in Table 6.17 the variables include; Strong private consortium (SPS1) has a loading point (0.663), True partnership (SPS2) with loading point (0.793), Open communication (SPS3) has a loading point (0.826), Social support (SPS4) also with loading point (0.800), Trust and openness between parties (SPS5) with loading point (0.743). Strong Private sector (SPS) Construct has a CR value of (0.878) and AVE value of (0.592). This indicate the Strong Private sector (SPS) model is significant with value that fall within acceptable value.

Strong private sector (SPS) relates to the capability of the private sector partners regarding technical competence, partnering experience and financial strength of the private sector partner to effectively handle PPP projects (Zhang, 2005).

Therefore, all the construct under the CSFs model as shown in Table 5.5 prove a significant improvement to which all the variables fall within acceptable value. This indicate that the CSFs of PPP is significant for affordable housing in Abuja Nigeria.

Therefore, It is necessary to choose a strong private developer who can provide affordable housing. The Nigerian government needs to work with a strong private sector to ensure that no political factors undermine its contractual partnership

\section{RECOMMENDATION AND CONCLUSION}

The main reason for PPP in housing is to provide adequate and affordable housing for all income groups. As a research find, PPP in the study area faces serious challenges in providing affordable housing. These challenges include acquisition and access to land, implementation of poor housing policies, adequate housing finance, access difficulties to mortgage facilities and land titles, large rural urban migration and cost recovery among others. Just like the previous public housing delivery strategy, this approach cannot be a home for high-income and middle-income earners in Abuja Nigeria.

However, provision of affordable housing has not yet been reached in the study area. The point that there is no consensus on the National Policy on PPP in housing in Nigeria is anxiety. Since PPP for affordable housing in Abuja Nigeria is unclear. Hence, it shows that PPP practices for affordable housing are then considered as governance controls as the main component of affordable housing. It is therefore recommended that a good policy framework for the implementation of other PPP variants in fulfilling affordable housing in Nigeria should be a consonant on the parameters of affordable housing constituencies.

First of all, it will wipe out all the undetermined constraints of local government authorities and grassroots organizations in PPP for affordable housing, and then provide the needs of different socioeconomic groups in the country's sub sector of housing in Nigeria. Land allocation and government rights documents at premium cost add to the cost of housing provided by PPP. To this end, the government may consider providing free land for affordable housing to ensure the capabilities and benefits of commercial commercial sector partners. We can also tread on the heels of Malaysia to provide affordable housing for all income groups, so that cheaper and local materials can be used instead of expensive and imported in building affordable housing units. Similarly, self-help options and government-assisted housing options should be incorporated into the PPP housing scheme to provide affordable housing for all income groups at a reasonable rate.

\section{REFERENCE}

ADB 2008. Public-Private Partnership Handbook. Mandaluyong City: Asian Development Bank.

Adedeji, Y. M. D. \& Olotuah, A. O. 2012. An Evaluation of Accessibility of Low-Income Earners to Housing Finance in Nigeria. American-Eurasian Journal of Scientific Research, 23-31.

Agbola, T. (1998)."The Housing of Nigerians: A Review of Policy Development and Implementation in the Housing Sector". Research Report 14, Ibadan Develoment Policy Center.

Alfen, H. W., Kalidindi, S. N., Ogunlana, S., Wang, S., Abednego, M. P., Frank-Jungbecker, A., Jan, Y.-C. A., Ke, Y., Liu, Y., Singh, L. B. \& Zhao, G. 2009. Public-Private Partnership in Infrastructure Development: a Case Studies from Asia and Europe, EAP3N.

Alter, C. \& Hage., J. 1993. Organizations working together, Newbury Park, Calif. : Sage

Publications, 1993.

Aluko, B. T. (2009). An Overview of Potential Issues in the Implementation of Public- Private 
Partnership Initiatives. A Paper Presented at 2009 MCPD Workshop of The Nigerian Institution of Estate Surveyors and Valuers (Osun State Branch).

Awotona, A. 1990. Nigerian Government participation in housing: 1970-1980. Habitat International, 14(1), 17-40.

Bain, R. \& Plantagie, J. W. 2007. The Anatomy Of Construction Risk: Lessons From A Millennium Of PPP Experience.

Bieri, D. S. 2012. Housing Affordability. Real Estate program, Urban \& Regional planning, University of Michigan, Ann Arbor, MI 48019, USA.

Börzel, T. A. \& Risse, T. 2002. Public-Private Partnerships: Effective and Legitimate Tools of International Governance?

CCPPP 2001. Benefits of Water Service Public-Private Partnerships The Canadian Council for Public Private Partnerships

CCSP 2011. Affordable Housing as a Platform for Improving Family Well-Being: Federal Funding and Policy Opportunities Financing Community Change Brief June 2011. Center for the Study of Social Policy

Duffield, C. \& Raisbeck, P. 2007. Performance of PPPs and Traditional Procurement in Australia. Melbourne: Infrastructure Partnerships Australia.

EIB 2004. The EIB's role in Public-Private Partnerships (PPPs). European Investment Bank.

Engel, E., Fischer, R. \& Galetovic, A. 2011. Public-Private Partnerships to Revamp U.S. Infrastructure.

EPEC 2011. The Non-Financial Benefits of PPPs A Review of Concepts and Methodology. European PPP Expertise Centre. L2950 Luxembourg: European PPP Expertise Centre.

Ernest Effah Ameyaw, Albert P.C. Chan, (2016) "Critical success factors for public-private partnership in water supply projects", Facilities, Vol. 34 Issue: 3/4, pp.124-160, https://doi.org/10.1108/ F-04-2014-0034

Finmarktrust 2010. Overview Of The Housing Finance Sector In Nigeria Access to Housing Finance in Africa. Lagos: Commissioned by EFInA and FinMark Trust.

Flinders, M. 2005. The Politics of Public-Private Partnerships. The British Journal of politics \& International Relations, Volume 7, 215 $-239$.

Gemade, T. 2011. Federal Housing Authority (FHA) Seeks Intervention Fund. Federal Hpusing Authority, Nigeria.

Ibem, E. O. \& Aduwo, E. B. 2012. Public-Private Partnerships (PPPs) in Urban Housing in Nigeria: Evidence from Ogun State. International Journal Of Architecture and Urban Development, 2.

Khanom, N. A. 2010. Conceptual Issues in Defining Public Private Partnerships. International Review of Business Research Papers, Volume 6. Number 2, Page 150 -163.

LAO 2012. Maximizing State Benefits From Public-Private Partnerships. Sacramento: The Legislative Analyst's Office.
Lagos State Government (2008) Lagos State Government PPP initiatives, PPP Brochure (Ikeja: Ministry Of Finance). Available at http://www.lagostate.gov.ng (accessed 14 May 2018).

Law, C. 1988. Public-Private Partnerships in Urban Revitalization in Britain. Regional Studies, Vol.22, pp.446 -451.

Linder, S. H. \& Rosenau, P. V. 2000. Mapping the Terrain of the Public-Private Policy Partnership. In Public-Private Policy Partnerships,Cambridge MA: MIT.

Ikejiofor, U. 1999. The God that failed: A critique of public housing in Nigeria, 1975-1995. Habitat International,, 177-188.

Kwak, Y. H., Chih, Y. Y. \& Ibbs, C. W. 2009. Towards a comprehensive understanding of Public Private Partnerships for infrastructure development. California Management Review, pp. 51 -78 .

Kissick, D., Leibson, D., Kogul, M., Bachmann, J., Anderson, J. \& Eckert, J. 2006. Housing for All: Essential to Economic, Social, and Civic Development. Prepared for The World Urban Forum III Vancouver in collaboration with The International Housing Coalition.

Kothari, M. 2005. UN Press Briefing by Special Rapporteur on the Right to Adequate Housing.

Mabogunje, A. L. 2011. Landreform Innigeria: Progress, Problems $\&$ Prospects. Presidential Technical Committee for Land Reform. Abuja: Nigerian Federal Government.

\section{NHP 2012. National Housing Policy. Abuja.}

Mabogunje, A. L. (1993). "New Paradigm for Urban Development in Africa" AKeynote Address Delivered at the1993 Annual Conference of the Canadian Association of African Studies held at the University Toronto, 12 th -15 th May.

Miraftab, F. (2004) Public-Private Partnerships: Trojan horse of neoliberal development? Journal of Planning Education and Research, 24(1), 89-101.

Moskalyk, A. 2008. The Role of Public-Private Partnerships in Funding Social Housing in Canada. CPRN Research Report. Canadian Policy Research Network.

Moszoro, M. 2010. Efficient Public-Private Partnerships. IESE Business School University of Navarra.

Ogunshakin, L. \& Olayiwola, I. 1992. The collapse of Social housing policy in Nigeria. Habitat International,, 41-53.

Owei, O. (2007) Distortions of the urban land markets in Nigerian cities and the implications for urbangrowth patterns; the case of Abuja and Port Harcourt. Paper presented at the Fourth Urban Research Symposium. Available at: http://www.Worldbank.org (accessed 22 June 2018).

Peters, G. 1998. Gething by with some help from our friends: Partnerships as Institutions.

Peters, G. \& Pierre, J. 1998. Governance Without Governement? Rethinking Public Administration. Journal of Public Administration Research and Theory, 223-243. 
Reinicke, W. H. \& Deng, F. 2000. Critical Choices. The United Nations, Networks, and the Future of Global Governance. . International Development Research Centre.

Sa-Aadu, J. 1984. Another Look at the Economics of Demand-Side Versus Supply-Side Strategies in Low-Income Housing. AREUEA, Vol. 12.

Salau, A. T. 1992. Urbanisation, housing and social services in Nigeria: The challenge of meeting basic needs, in Porter R. B. and Salau A. T. (eds) Cities and development in the Third World, England.

Shambaugh, J. B. 1999. The Role of the Private Sector in Providing Urban Water Supply Services in Developing Countries: Areas of Controversy. UNDP/Yale Collaborative Programme on the Urban Environment, Yale School of Forestry and Environmental Studies

Shelter Afrique (2008) Mortgage financing for increased access to housing inAfrica, Symposium organized jointly by Shelter Afrique and the Ministry of Housing, republic of Togo, Lome, 10 June. Available at: http://www.shelterafrique.org (accessed 15 July 2018).

Solomon Olusola Babatunde, Akintayo Opawole, Olusegun Emmanuel Akinsiku, (2012) "Critical success factors in public-private partnership (PPP) on infrastructure delivery in Nigeria", Journal of Facilities Management, Vol. 10 Issue: 3, pp.212-225, https://doi.org/10.1108/14725961211246018

Susilawati, C. 2009. Building a Successful Partnership to Increase Affordable Rental Housing Supply in Queensland. Doctor of Philosophy, Queensland University.

Teiseman, G. \& Klijn, E. H. 2002. Partnership Agreements: Governmental Rhetoric or Governance Scheme? Public Administration Review, Vol. 62, No. 2, pp. 35-51.

UN-Habitat 2015. Housing \& slum upgrading. Kenya: United Nations Human Settlements Programme

UN-Habitat 2006. National Trends in Housing-Production Practices. Nigeria.

UN-Habitat 2005. Financing Urban Shelter, Global Report on Human Settlements. Nairobi: United Nation.

USAID 2002. Tools for alliance Builders. Washington D.C: United States Agency for International Development.

Walley, S. 2010. Housing Finance in Africa: Are we Post Crisis Yet?". African Union of Housing Finance Conference.

Weihe, G. 2006. Public-Private Partnerships: Addressing a Nebulous Concept Paper presented at the 10th Annual Research Symposium on Public Management Glasgow Caledonian University, Scotland.

Winch, G., Gunawansa, A., Schmidt, S. \& Onishi, M. 2012. Taking Stock of PPP and PFI around the World. London: Certified Accountants Educational Trust.

Woetzel, J., Ram, S., Mischke, J., Garemo, N. \& Sankhe, S. 2014. A blueprint for addressing the global affordable housing challenge. McKinsey Global Institute. 